\title{
Study on Microorganism Distribution Characteristics of Three Types of Typical Acidified Soils
}

\author{
Tianxin $\mathrm{Li}^{1}$, Linglong Meng ${ }^{1}$, Nana $\mathrm{Li}^{2 *}$, Yikun Zhao ${ }^{1}$, Herman Uwizeyimana ${ }^{1}$ \\ ${ }^{1}$ Civil and Environmental Engineering school, University of Science and Technology Beijing, Beijing 100083 China. \\ ${ }^{2}$ CNNC Beijing Research Institute of Uranium Geology, Beijing 100029 China. \\ Corresponding author: Nana Li, E-mail: 791085007@139.com
}

\begin{abstract}
The acidified soil caused by the acid rain has become a global problem, however, its effects to the microorganisms in the soil is not well understood. The authors employed a series of physiological and biochemical experiments to test and analyze three typical acidified and the remediated soil like grassland soil on barren hills, masson pine soil, and mixed coniferous and broad-leaved forest soils. The observation shows that the number and categories of microorganisms decreased in the order bacteria> epiphyte >actinomycetes, and the number of microorganisms in different depth of soil decreased in the order $0 \sim 20 \mathrm{~cm}>20 \sim$ $40 \mathrm{~cm}>40 \sim 60 \mathrm{~cm}$.Moreover, separation and identification of bacteria indicates that preponderant bacteria in different soils were distinguishing, so were the soil before and after remediation with the change of soil $\mathrm{pH}$.The results enable us to further understand the characteristics of the remediated acidified soil from the aspect of microbiology.
\end{abstract}

Keywords-acidified soil; biological activities; bacteria identification; remediated soil.

\section{INTRODUCTION}

Microorganism is one of the significant components in soil ecosystems. The soil microorganism including bacteria, epiphyte and actinomycetes, involved in almost all biochemical reactions in soils can play an important role in maintaining soil quality, decomposing relicts of propagation as well as organic and harmful substances in soil, and regulating biochemical cycling and formation process of soil structure, and serves as a significant indicator of soil fertility [1], [2]. Generally, most bacteria and actinomycetes live in the environment with neutral or alkaline $\mathrm{pH}$, while the suitable living environment for epiphyte is acidic and most actinomycetes and epiphyte are limited under aerobic conditions [3]. The study on quantity, type and activity of microorganism in acidified soil contribute to exploring the mechanism of soil acidification and soil fertility status and therefore exhibits vital reference value to the remediation of acidified soil.

\section{METHODS, RESULTS AND DisCUSSION:}

\section{A. Soil sample}

i) Soil before remediation

The soil samples were collected from Longli ecological park with small watershed named LongliYangjichong as a unit in the upper branch of Sanyuan River in Wujiang River System where serious sulfuric acid rain happens due to the high level of sulfate radical. This area is located in Guizhou, China where the most typical acid soil is found. The acidified soils in this area were categorized into three fields: (1) Acid soil developing from sandstone, mostly covered by grassland on barren hills; (2) Acid soil developing from sandstone, mostly covered by masson pine forest; (3) Acid soil developing from limestone, mostly covered by mixed broadleaf-conifer forest (mixed wood).

Table I. Primary Physical And Chemical Properties Of The SoIl SAmples

\begin{tabular}{|c|c|c|c|c|c|c|c|c|c|c|c|}
\hline \multirow{2}{*}{$\begin{array}{l}\text { Soil } \\
\text { type }\end{array}$} & \multirow{2}{*}{ Depth(cm) } & \multirow{2}{*}{$p H$} & \multicolumn{6}{|c|}{ Exchangeable cation $(\mathrm{mmol} / \mathrm{kg})$} & \multirow{2}{*}{$\begin{array}{c}C E C \\
(\mathrm{mmol} / \mathrm{kg})\end{array}$} & \multirow{2}{*}{$B S(\%)$} & \multirow{2}{*}{ A1S $(\%)$} \\
\hline & & & $\mathrm{Ca}^{2+}$ & $\mathrm{Mg}^{2+}$ & $K^{+}$ & $\mathrm{Na}^{+}$ & $H^{+}$ & $A l^{3+}$ & & & \\
\hline \multirow{3}{*}{ Masson Pine Forest } & $0 \sim 20$ & 4.33 & 5.13 & 0.91 & 1.41 & 0.26 & 8.53 & 98.06 & 114.30 & 6.74 & 85.79 \\
\hline & $20 \sim 40$ & 4.45 & 4.70 & 0.43 & 0.98 & 0.28 & 7.29 & 83.24 & 96.92 & 6.59 & 85.88 \\
\hline & $40 \sim 60$ & 4.68 & 3.65 & 0.47 & 1.45 & 0.23 & 3.01 & 43.52 & 52.33 & 11.08 & 83.16 \\
\hline \multirow{3}{*}{ Mixed Wood } & $0 \sim 20$ & 5.68 & 18.30 & 6.43 & 1.79 & 0.42 & 6.31 & 18.75 & 51.99 & 51.81 & 36.06 \\
\hline & $20 \sim 40$ & 5.87 & 12.97 & 7.87 & 1.03 & 0.46 & 5.63 & 14.53 & 42.48 & 52.55 & 34.20 \\
\hline & $40 \sim 60$ & 5.89 & 11.25 & 6.97 & 1.20 & 0.41 & 5.99 & 20.54 & 46.36 & 42.77 & 44.31 \\
\hline \multirow{3}{*}{ Grassland on Barren Hills } & $0 \sim 20$ & 4.21 & 3.41 & 2.53 & 1.77 & 1.01 & 3.72 & 4.19 & 54.48 & 85.48 & 7.69 \\
\hline & $20 \sim 40$ & 4.43 & 2.74 & 1.47 & 1.39 & 0.21 & 3.27 & 3.85 & 50.89 & 86.02 & 7.57 \\
\hline & $40 \sim 60$ & 4.59 & 2.03 & 0.93 & 1.39 & 0.23 & 3.30 & 1.16 & 46.44 & 90.40 & 2.50 \\
\hline
\end{tabular}

Annotate: CEC—Cation Exchange Capacity; BS—-percentage content of base cation in CEC, namely Base Saturation; A1S—-percentage content of A1 in CEC, namely A1 Saturation: A1S (\%) $=100 \sum(\mathrm{A} 13+) / \mathrm{CEC}$. 
ii) Remediated soil

The research of remediating the three types of acidified soil was performed through the model of soil columns equipment in laboratory. According to the characteristics of the acid rain in the experiment area, remediation agent were added to the acidified soil in Guizhou, under simulated Acid-rain Leaching. By observing the remediation effect, we find the best way to remediate the three types of acidified soil as follows: (1) $150 \mathrm{~g}$ of dolomite and $150 \mathrm{~g}$ of magnesite for per square meter of grassland soil, (2) $300 \mathrm{~g}$ of magnesite for per square meter of masson pine soil, (3) $300 \mathrm{~g}$ of dolomite for per square meter of mixed coniferous and broad-leaved forest soil. In addition, all of the best adding approaches was to dissolve these powders into 500L water and to leach the soils.

\section{B. Means of microorganism test and analysis}

With the method of dilution-plate coating, we carried out gradient dilution respectively to three soil depth $(0 \sim$ $20 \mathrm{~cm}, 20 \sim 40 \mathrm{~cm}$ and $40 \sim 60 \mathrm{~cm}$ ) of three types of soils taken from the three types of the acid soils. The microorganisms were cultured on culture medium plate of corresponding physiological groups that were smeared by $0.1 \mathrm{ml}$ of soil suspension with appropriate dilution degree at $30^{\circ} \mathrm{C}$. The bacteria, epiphyte and actinomycetes were respectively counted 1 2days later[4].

i) Isolation and purification of bacteria

The strain was isolated with plate streaking method and dilution-plate method. We chose five kinds of dominant bacteria from every type of soil before and after remediation, and performed culture rotation regularly[4].

ii) Experiment of morphological character of soil bacteria

Experiment of Gram stain[5]: Bacteria were categorized into gram-negative bacteria (G-) and gram-positive bacteria $(\mathrm{G}+)$ according to the differences in bacterial cell wall structure and composition.

Motility experiment: After cultivation, the measured strain was named negative when the thalligrowth was limited in the growth line and with clear edge while the mobile strain was named positive when the thalli proliferated nebulously.

iii) Three types of acidified soil bacteria's physiological and biochemical experiment

Physiological and biochemical experiments were performed on dominant bacteria selected from the three types of soils, including aerobic experiment, sugar fermentation experiment, nitrate reduction experiment, citrate utilization experiment, starch hydrolysis experiment, fat hydrolysis experiment, urea hydrolysis experiment, litmus milk experiment, oxidase experiment, contact enzyme (catalase) activity experiment, gelatin liquefaction experiment, methyl red (MR) experiment, acetyl methyl alcohol (VP) experiment, produce hydrogen sulfide experiment, produce indole experiment.

\section{Counting statistical analysis of microorganism in three} types of soil

Plate count was carried out on total number of microorganism, bacteria, actinomycetes, epiphyte in different depths of three types of acidified soils. The results are shown in Figure1,2,3and 4.

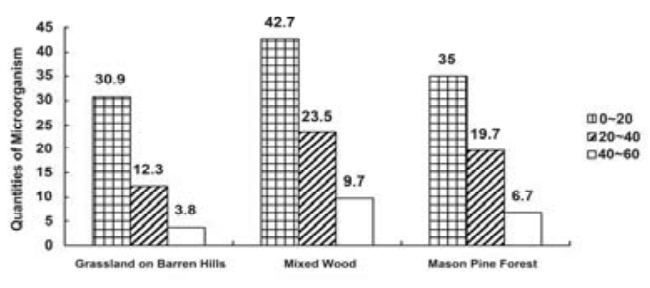

Figure 1. Quantities of microorganisms

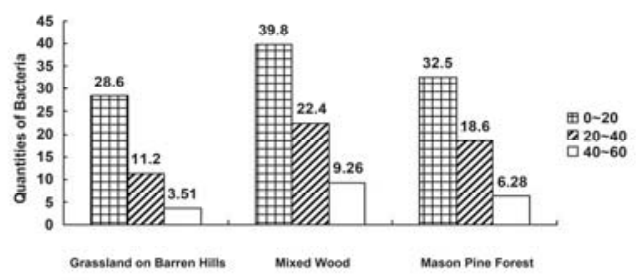

Figure 2. Quantities of bacteria

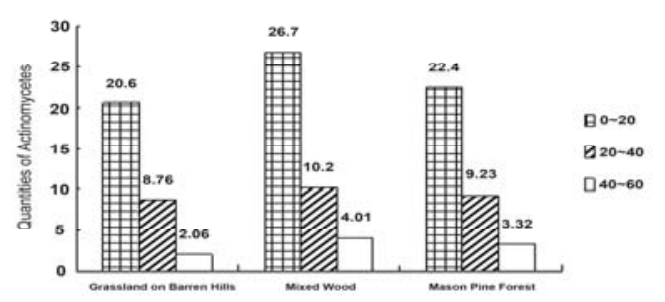

Figure 3. Quantities of actinomycetes

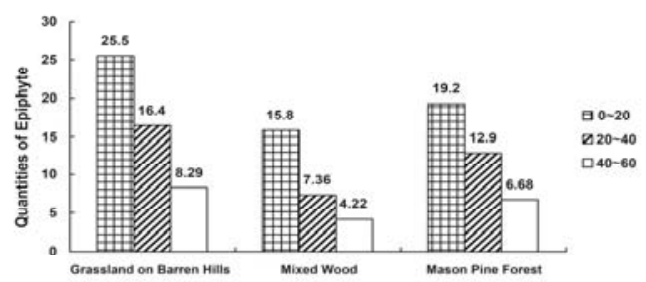

Figure 4. Quantities of epiphytes

The above four figures indicate that in the three types of soils, microorganic quantity declines sharply along with the deepening of the soil. In surface soil, the decomposed leaves and weed can transform into the soilthatcan produce a thick humus layer rich in organic matter, the total $\mathrm{N}$ and hydrolytic $\mathrm{N}$ that can be conducive to microbial activity. At the same time, soil surface temperature and ventilation conditions are conducive to microbial survival and reproduction, therefore, the quantity of soil microorganism in the surface soil is the largest.Furthermore, the difference 
in the number of soil microorganism between the depth of $20 \sim 40 \mathrm{~cm}$ and $40 \sim 60$ is smaller than that between the depth of $0 \sim 20$ and $20 \sim 40 \mathrm{~cm}$, which can be due to that with the soil depth, soil structure, nutrients, moisture, temperature, ventilation condition become stable that can result in the slight difference in the number of underlying microorganism.

The antiacid ability of the three types of soil is as follows: mix wood >masson pine forest $>$ grassland on barren hills due to more bacteria and actinomycetes exist in neutral or alkaline environment while acidic environment is suitable for epiphyte. Therefore, more bacteria and actinomycetes exist in mix wood while more epiphyte in grassland on barren hills where soil acidification is more serious. The horizontal comparison of the microorganic quantity in three types of soil indicates that the acid resistance of the microorganisms is positively correlated to the biological.

\section{Result and analysis}

The 15 dominant bacteria in the three types of acidified soil were selected after separation and purification from the plates. Another five kinds of dominant bacteria in the three types of remediated soil were selected after separation and purification. The results of character experiment are as follows.

i) The experiment result of bacterial morphological character

The result of Gram stain experiment shows that before and after remediation of the three types of acidified soil, dominant bacteria in soil are almost negative from the viewpoint of strain's polarity, and morphology of strain changes slightly from the viewpoint of morphology. In details: In the soil of grassland on barren hills, strains were mainly rod-shape, spiral shape and club-shape; In the soil of masson pine forest, strains were mainly rod-shape, clubshape and short and thick rod-shape; In the soil of mix wood, strains were mainly rod-shape and round shape.

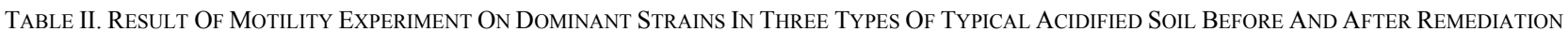

\begin{tabular}{|c|c|c|c|c|c|c|c|c|c|c|}
\hline SN & H1 & $\mathrm{H} 2$ & H3 & H4 & H5 & H6 & $\mathrm{H} 7$ & H8 & H9 & H10 \\
\hline $\mathrm{M}$ & + & + & + & + & + & - & + & + & + & + \\
\hline SN & M1 & M2 & M3 & M4 & M5 & M6 & M7 & M8 & M9 & M10 \\
\hline $\mathrm{M}$ & - & + & - & + & + & - & - & - & + & + \\
\hline $\mathrm{SN}$ & $\mathrm{Z1}$ & $\mathrm{Z} 2$ & $\mathrm{Z3}$ & Z4 & $\mathrm{Z} 5$ & Z6 & $\mathrm{Z7}$ & Z8 & Z9 & $\mathrm{Z} 10$ \\
\hline $\mathrm{M}$ & + & - & + & + & - & + & - & + & + & - \\
\hline
\end{tabular}

We can find that almost strains in grasslands on barren hills can move while 60 percent of the strains can move in masson pine forest and mix wood. hills

ii) Identification result of strains in grassland on barren

Table 3 indicates that the five kinds of dominant strains were identified before the remediation of soil in grassland on barren hills, in which there were acidophilic Alcaligenes and Bacillus except Pseudomonas, Spirillum and
Agrobacteriumcommon in soil. When the Alcaligeneswas in acidic environment,it could produce alkali to maintain the acid-basicity of growth environment. The Bacillus acidocaldarius and Bacillus pantothenticus belonging to the Bacillus can grow in acidic environment, especially bacillus acidocaldarius can grow in distinct acidic water and soil which can indicate that the acid-basicity of soil can have a direct impact on diversity of bacterial colony.

TABLE III. IDENTIFICATION RESUlt OF DOMINANT Strains In SOIL OF GRASSLAND ON BARREN HiLLS BEFORE REMEDIATION

\begin{tabular}{|l|l|l|l|l|l|}
\hline SN & H1 & H2 & H3 & H4 \\
\hline $\begin{array}{l}\text { becteria } \\
\text { genus }\end{array}$ & $\begin{array}{l}\text { Pseudomonas } \\
1894,237\end{array}$ & Migula & $\begin{array}{l}\text { Spirillum Ehrenberg } \\
1832,38\end{array}$ & $\begin{array}{l}\text { Agrobacterium } \\
\text { Conn 1942,359 }\end{array}$ & $\begin{array}{l}\text { AlcaligenesCastellani\& } \\
\text { Chalmers, } 1919,936\end{array}$ \\
\hline S/M & $0.5-1 \times 1.5-4$ & $0.25-1.7$ & $0.8 \times 1.5-3.0$ & $\begin{array}{l}\text { Bacillus } \\
\text { Cohn } 1872,174\end{array}$ \\
\hline GT & $4-43^{\circ} \mathrm{C}$ & $30^{\circ} \mathrm{C}$ & $25-30^{\circ} \mathrm{C}$ & $20-37^{\circ} \mathrm{C}$ & $0.3-2.2 \times 1.2-7.0$ \\
\hline $\mathrm{G}+\mathrm{C}$ & $58-70$ & $38-65$ & $59.6-62.8$ & $57.9-70$ & $32-62$ \\
\hline GP & $7.0-8.5$ & - & $6.0-9.0$ & 7.0 & $5.5-8.5$ \\
\hline
\end{tabular}

Annotate: SN-Serial number;S/M-Size/micron;GT-Growth temperature;G+C-G+C content in DNA/mol\%;GP-Growth pH, similarly hereinafter. 
TABLE IV. IDENTIFICATION RESUlt Of DOMINANT Strains In SOIL OF GRASSLAND ON BARREN HiLls AfTER REMEDIATION

\begin{tabular}{|c|c|c|c|c|c|}
\hline SN & H6 & $\mathrm{H} 7$ & H8 & H9 & H10 \\
\hline $\begin{array}{l}\text { becteria } \\
\text { genus }\end{array}$ & $\begin{array}{l}\text { AcinetobacterBrisou\&Prevot } \\
1954,727\end{array}$ & $\begin{array}{l}\text { Spirillum Ehrenberg } \\
1832,38\end{array}$ & $\begin{array}{c}\text { Agrobacterium Conn } \\
1942,359\end{array}$ & $\begin{array}{l}\text { AlcaligenesCastellani\& } \\
\text { Chalmers, } 1919,936\end{array}$ & $\begin{array}{c}\text { Pseudomonas } \\
\text { Migula 1894,237 }\end{array}$ \\
\hline $\mathrm{S} / \mathrm{M}$ & $1.0-1.5 \times 1.5-2.5$ & $0.25-1.7$ & $0.8 \times 1.5-3.0$ & $0.5-1.2 \times 0.5-2.6$ & $0.5-1 \times 1.5-4$ \\
\hline GT & $30-32^{\circ} \mathrm{C}$ & $30^{\circ} \mathrm{C}$ & $25-30^{\circ} \mathrm{C}$ & $20-37^{\circ} \mathrm{C}$ & $4-43^{\circ} \mathrm{C}$ \\
\hline $\mathrm{G}+\mathrm{C}$ & $40-47$ & $38-65$ & $59.6-62.8$ & $57.9-70$ & $58-70$ \\
\hline GP & 7.0 & $\longrightarrow$ & $6.0-9.0$ & 7.0 & $7.0-8.5$ \\
\hline
\end{tabular}

TABle V. Identification Result Of Dominant Strains In SOIL Of MASSOn Pine Forest Hills Before ReMEdiation

\begin{tabular}{|c|c|c|c|c|c|}
\hline $\mathrm{SN}$ & M1 & M2 & M3 & M4 & M5 \\
\hline $\begin{array}{l}\text { bacteria } \\
\text { genus }\end{array}$ & $\begin{array}{c}\text { AzotobacterBeijerinck } \\
1991,567\end{array}$ & $\begin{array}{l}\text { Derxia Jensen, Peterson, De \& } \\
\text { Bhattacharya, 1960,193 }\end{array}$ & $\begin{array}{c}\text { BrucellaMeyer\&Shaw } \\
1920,173\end{array}$ & $\begin{array}{c}\text { Agrobacterium Conn } \\
1942,359\end{array}$ & $\begin{array}{c}\text { Bacillus Cohn } \\
1872,174\end{array}$ \\
\hline $\mathrm{S} / \mathrm{M}$ & $2 \times 5$ & $1.0-1.2 \times 3.0-6.0$ & $0.5-0.7 \times 0.6-1.5$ & $0.8 \times 1.5-3.0$ & $0.3-2.2 \times 1.2-7.0$ \\
\hline GT & $20-30^{\circ} \mathrm{C}$ & $25-35^{\circ} \mathrm{C}$ & $20-40^{\circ} \mathrm{C}$ & $25-30^{\circ} \mathrm{C}$ & - \\
\hline $\mathrm{G}+\mathrm{C}$ & $63-66$ & 70.4 & $56-58$ & $59.6-62.8$ & $32-62$ \\
\hline GP & $5.5-8.5$ & $5.5-9.0$ & $6.6-7.4$ & $6.0-9.0$ & $5.5-8.5$ \\
\hline
\end{tabular}

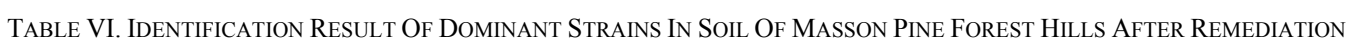

\begin{tabular}{|c|c|c|c|c|c|}
\hline SN & M6 & M7 & M8 & M9 \\
\hline $\begin{array}{c}\text { bacteria } \\
\text { genus }\end{array}$ & $\begin{array}{c}\text { AzotobacterBeijerinck } \\
1991,567\end{array}$ & $\begin{array}{c}\text { Clostridium } \\
\text { Prazmowski } 1882,23\end{array}$ & $\begin{array}{c}\text { BrucellaMeyer\&Shaw } \\
1920,173\end{array}$ & $\begin{array}{c}\text { Agrobacterium Conn } \\
1942,359\end{array}$ & $\begin{array}{c}\text { Pseudomonas Migula } \\
1894,237\end{array}$ \\
\hline S/M & $2 \times 5$ & $0.6-1.2 \times 3.0-7.0$ & $0.5-0.7 \times 0.6-1.5$ & $0.8 \times 1.5-3.0$ \\
\hline GT & $20-30^{\circ} \mathrm{C}$ & $25-37^{\circ} \mathrm{C}$ & $20-40^{\circ} \mathrm{C}$ & $25-30^{\circ} \mathrm{C}$ & $0.5-1 \times 1.5-4$ \\
\hline $\mathrm{G}+\mathrm{C}$ & $63-66$ & $23-43$ & $56-58$ & $4-43^{\circ} \mathrm{C}$ \\
\hline $\mathrm{GP}$ & $5.5-8.5$ & - & $6.6-7.4$ & $6.0-62.8$ & 5.0 \\
\hline
\end{tabular}

TABLE VII. IDENTIFICATION ReSUlt Of Dominant Strains In SOIL OF Mix WoOd Before Remediation

\begin{tabular}{|c|c|c|c|c|c|}
\hline $\mathrm{SN}$ & $\mathrm{Z1}$ & $\mathrm{Z} 2$ & $\mathrm{Z3}$ & $\mathrm{Z4}$ & $\mathrm{Z} 5$ \\
\hline $\begin{array}{l}\text { bacteria } \\
\text { genus }\end{array}$ & $\begin{array}{c}\text { BeijerinckiaDerx } \\
1850,145\end{array}$ & $\begin{array}{c}\text { Sporosarcinaureae(Beijerinck) } \\
\text { Kluyver\&vanNiel } \\
1936,401\end{array}$ & $\begin{array}{l}\text { Agrobacterium } \\
\text { Conn } \\
1942,359\end{array}$ & $\begin{array}{l}\text { AlcaligenesCastellani\& } \\
\text { Chalmers, 1919,936 }\end{array}$ & $\begin{array}{c}\text { NitrobacterWinogradskr } \\
1892,127 \text { nom. cons }\end{array}$ \\
\hline $\mathrm{S} / \mathrm{M}$ & $0.5-1.5 \times 1.7-4.5$ & $\varphi 1.2-2.5$ & $0.8 \times 1.5-3.0$ & $0.5-1.2 \times 0.5-2.6$ & $0.6-0.8 \times 1.0-2.0$ \\
\hline GT & $10-35^{\circ} \mathrm{C}$ & $22-30^{\circ} \mathrm{C}$ & $25-30^{\circ} \mathrm{C}$ & $20-37^{\circ} \mathrm{C}$ & $5-40^{\circ} \mathrm{C}$ \\
\hline $\mathrm{G}+\mathrm{C}$ & $50.4-60.7$ & $40-43$ & $59.6-62.8$ & $57.9-70$ & $60.7-61.7$ \\
\hline GP & $3-9.5$ & $6.4-9.4$ & $6.0-9.0$ & 7.0 & $6.5-8.5$ \\
\hline
\end{tabular}

TABLE VIII. IDENTIFICATION RESULT OF DOMINANT STRAINS IN SOIL OF MIX WOOD AFTER REMEDIATION

\begin{tabular}{|c|c|c|c|c|c|}
\hline SN & Z6 & Z7 & Z8 & Z9 & Z10 \\
\hline $\begin{array}{c}\text { Bacteria } \\
\text { genus }\end{array}$ & $\begin{array}{c}\text { Rhizobium } \\
\text { Frank 1889,338 }\end{array}$ & $\begin{array}{c}\text { Sporosarcinaureae } \\
\text { (BeijerinckKluyver } \\
\text { \&vanNiel }) 1936,401\end{array}$ & $\begin{array}{c}\text { Agrobacterium } \\
\text { Conn 1942,359 }\end{array}$ & $\begin{array}{c}\text { AzomonasWinogradsky } \\
1938,391\end{array}$ & $\begin{array}{c}\text { NitrobacterWinogradskr } \\
1892,127 \text { nom. cons }\end{array}$ \\
\hline S/M & $0.5-0.9 \times 1.2-3.0$ & $\varphi 1.2-2.5$ & $0.8 \times 1.5-3.0$ & $0.6-0.8 \times 1.0-2.0$ \\
\hline GT & $25-30^{\circ} \mathrm{C}$ & $22-30^{\circ} \mathrm{C}$ & $25-30^{\circ} \mathrm{C}$ & $20-30^{\circ} \mathrm{C}$ & $5-40^{\circ} \mathrm{C}$ \\
\hline G+C & $59.1-65.5$ & $40-43$ & $59.6-62.8$ & $60.7-61.7$ & $6.5-8.5$ \\
\hline GP & $5.0-8.5$ & $6.4-9.4$ & $6.0-9.0$ & 7.5 & \\
\hline
\end{tabular}

Table 4 indicates that in the soil after remediation, the dominant strains were different from those before remediation indicating that the microorganic environment of had improved to a certain extent.

iii) Identification result of strains in masson pine forest
Table 5 indicates the existence of Derxia and Bacillus in the soil of masson pine forest due to the stronger acidity before remediation which is suitable for the acid-resistant colonies. 
Table 6 shows that in the soil of masson pine forest after remediation, the dominant strains are different from that before remediation Clostridium and Pseudomonas had dominated rather than Derxia and Bacillus growing in acidic environment. After the remediation of acidic soil, dominant strains altered because of the change of hydroniums and nutrients in soil and the change of soil's $\mathrm{pH}$ which shows that soil remediation technology can improve the characteristics of the soil.

iv) Identification result of strains in mix wood

Table 7 indicates that the dominant strains in the soil of mix wood contain the common Agrobacterium and Nitrobacter. In the dominant strains, there were Beijerinckia (Beijerinckia that can produce acid in neutral and alkalinous environment, alkaline matter in strong acidic culture medium to improve the $\mathrm{pH}$ value of environment is widespread in intertropical acidic soil)[11] and Alcaligenes who can maintain acid-basicity of environment.

After remediation, the dominant strains in the soil of mix wood changed due to the change of soil $\mathrm{pH}$, the improvement of acidic environment, the recovery of leaching ion and the improvement of ion and nutrients. Beijerinckia and Alcaligenes were replaced by Rhizobium and Azomonas.

\section{CONCLUSIONS}

From the quantitative analysis of three types of soil microorganism, the microorganic activity is as follows: soil in mix wood $>$ soil in masson pine forest $>$ soil in grassland on barren hills which can demonstrate that in the three types of soil, the soil in mix wood possesses the best acid resistance and buffer capacity.

The identified genus can indicate that dominant strains changed because of soil acidification. The acid-resistant strains or those which can produce alkali began to dominate. However, in the soil after remediation, instead of the genus that is acid-resistant or adapted to acidic environment, there were some strains of the common genus in soil that are adapted to neutral environment. In the remediated soil, the common genus adapted to neutral environment could replace the acid-resistant genus and those strains welladapted to the acid environment.
The separation and identification of soil microorganism can lay the foundation for further research of soil acidification mechanism and the results of this study will provide a meaningful guidance for the remediation of acidified soil.

\section{ACKNOWLEDGEMENTS}

This project is supported by National Basic Research Fund of Chinese Ministry of Education (No. FRF-SD-12008A).

\section{REFERENCES}

[1]Ma Fang, FengYujie, RenNanqi, 2003.Environmental Biology Technology.Beijing: Chemical Industry Press. (in Chinese).

[2] Pascual J A, Garcia P C, Hcrndcz T, 2000.Soil microbial activity as abiomarkerof degradation and remediation processes. Soil Biology\&Biochemistry, 32: $1877 \sim$ 1882. PII: S0038-0717 (00)00161-9.

[3] Jiao Xiaodan, Wu Fengzhi, 2004.Progress of soil microbial diversity research method.Chinese Journal of Soil Sciences.35(6): $789 \sim 792$.

[4] ZhongWenhui, CaiZucong, 2004. Methods for studying soil microbial diversity. Chinese Journal of Applied Ecology.15 (5): 899 904. DOI: 1001-9332(2004)05-0899-06.

[5] Chen Chengli, Liao Min, ZengLusheng, 2006. Methods to measure the microbial community structure and functional diversity in polluted soils. ActaEcologicaSinica.26(10): $3404 \sim 3412$. DOI: 10000933(2006)10-3404-09.

[6] Zhang,JiaenCaiYanfei, GaoAixia, 2004. Review on laboratory methods for soil microbial diversity. Soils,36(4): 346 350.

[7] Andersson S, Nikon S I, 2001. Influence of $\mathrm{pH}$ and temperature on microbial activity,substrate availability of soil-solution bacteria and leaching of dissolved organic carbon in a mor humus. Soil Biology and Biochemistry,33(9): 1181 1191. PII: S0038-0717(01)00022-0.

[8] TengYing, Huang Changyong, LuoYongming, 2004. Microbial activities and functional diversity of community in soils polluted with $\mathrm{Pb}-\mathrm{Zn}$-Ag mine tailings. ActaEcologicaSinica,41(1):1 13 119 .

[9] Graeme W.Nicol, L. Anne Glover, James L. Prosser, 2003. Spatial analysis of archaeal community structure in grassland soil.Appl Environ Microbiol, 69: $7420 \sim 7429$. DOI: 10.1128/AEM.69.12.7420-7429.2003.

[10] Yao Bin, XuJianming,ZhangChaolan. Effects of metsulfuron-methyl on microbial diversity in Paddy soil.ActaEcologicaSinica,2004, 41(2): $320 \sim 322$.

[11] Zuoqiang Han, Xilin Zhang, Yanjiao Qiao et al. Alkaline ameliorants increase nitrous oxide emission from acidified black soil in Northeastern China. Journal of Environmental Sciences, 2011,23(7):S45-S48 